\title{
An Onomastic Autobiography, or, In the Beginning Was the Name
}

\author{
W.F.H. Nicolaisen \\ University of Aberdeen
}

On Monday, June 13, 1927, at a quarter to two in the afternoon, Frau Paula Elisabeth Nicolaisen, herself twenty-three years old and only in the seventh month of her first pregnancy, gave birth to a son, weighing just over five pounds, to whom she and her husband, Andreas Wilhelm Albert Nicolaisen, gave the three names Wilhelm Fritz Hermann (1). ${ }^{1}$ These three names, confirmed in baptism on August 28, 1927, have, for over 70 years, been the official forenames of your honoree individualizing him, in conjunction with his surname, in society and distinguishing him from all other Nicolaisens in a fairly large family. One might say that such a triple designation sanctioned by state and church should have been sufficient identification for the little male baby as well as the retired professor, and in a very limited sense this has been the case, of course, but the mere fact that I am often introduced or referred to as Bill Nicolaisen and the realization that the Wilhelm Fritz Hermann Nicolaisen has probably been my least used appellation over seven decades (so rarely, in fact, that to many people who have known me for a long time, this is news), are clear indications that the official birth certificates, even when supported by the ecclesiastical powers that be, are severely restricted in their application and documentary value. It is probably true to say that I have been officially Wilhelm Fritz Hermann Nicolaisen only to issuers, perusers and processors of such and similar documents (like passports, marriage licenses, visas, and so on), and not to anybody else, and that consequently the actualization of my identity has almost exclusively been expressed in other, unofficial, onomastic terms. It is this variety of names that I have been called over the years by different people, in different situations, in different languages, in different registers, and that have shaped me as a person during that time, have made me and labeled me, that I want to parade and discuss in this "onomastic autobiography," in an account of "My Names and I," if you like. ${ }^{2}$ 
Before I do so, however, allow me briefly to return to the Wilhelm Fritz Hermann of my birth certificate because, unrelated to the practical demands of daily living as this triad of names may be, they anchor me firmly in my family and even in a little bit of German history. In particular, they make me the onomastic descendents of my closest male ancestors, my father and my two grandfathers. My father (2) bestowed on me the name Wilhelm, the middle one of his three forenames, the other two of which were never used. I am therefore undoubtedly my father's son; the complications which such identical naming can produce I will refer to later. I am, however, also my two grandfathers' grandson, not just genetically but also onomastically, for Fritz Nicolaisen was my father's father and Hermann Kähler my mother's father (3). According to the prevailing naming practices at the time, I could therefore not be mistaken for anything else but what I was: The eldest son of my father's and the eldest grandson of my grandfathers'; my names said and still say so quite clearly, and there is no escaping from this status. Fortunately, the chains which this onomastic triplet has placed on me have been very light, even comfortable, sartorial items, and I have never thought of them as a burden or felt the need to divest myself of them in any mood of protest or resentment or because of a feeling of inappropriate identity. Of these three names, Wilhelm has further implications because my father was named after one of his uncles, and his uncle bore the name of the first German Kaiser, demonstrating my ultimate onomastic involvement in the German monarchy, with a chronological depth of about 125 years. One does not have to be a name scholar to recognize that a tripartite combination like Wilhelm Fritz Hermann was a little old-fashioned even in 1927, the year of my birth, and could easily have been given a generation or two earlier. In this connection, it is worth mentioning that all three names cannot, and in 1927 would not, deny their patently Germanic origins or flavor although their lexical etymologies never entered into my naming: I am not, never have been, and my parents never thought of me as a "helmet of resolution;" nor am I someone "mighty in peace" or an "army-man." My onomastic persona was created under the fairly conservative, social pressures of the time which assigned it a clearly appointed place in my family genealogy. "Eldest son and grandson is the onomastic content of my forenames, and that is good so (In parentheses, I should add that my Jutland surname, Nicolaisen, of course, also no longer corresponds to its lexical meaning "son of Nicolai or Nicholas;" if patronymic surnames had not yet become hereditary in Danish at the time of my birth, I would naturally have been Wilhelmsen or perhaps Andresen). Lexically, therefore, I am a fraud, but onomastically my individual niche could not have been more definitely and appropriately selected.

Once the birth certificate had been filed and the drops of water that had been sprinkled on my forehead at the baptismal font had dried, however, good old (or young) Wilhelm Fritz Hermann had seemingly been 
filed and dried with them, for even a photograph which shows me as a three-months old in my mother's arms is signed by her on my as yet preliterate behalf as Klein-Willi "little Willi," distinguishing me not just in size and age but also in name from my father who was always known in the family as Willi. I see the addition of Klein- to my name not as a belittling act but rather as a small but significant gesture of providing me with an identity different from my father's, an early step in the direction of becoming myself.

Exactly how long this designation lasted is difficult to tell in retrospect, but undoubtedly a further emancipatory move on the onomastic front had taken place before I was two years old because the next photograph that can be dated is signed, in my mother's handwriting, by somebody called Putzi (4). How the transformation from Klein-Willi to Putzi came about, I cannot now say since there is no phonological law in the Indo-European languages from Verner's to Grimm's, no Lautverschiebung known to learned linguists, which would explain even with a high degree of speculation and uncertainty this curious metamorphosis. I have a suspicion that it is the combined effect of early babbling by its bearer (perhaps ineptly echoing the German adjective putzig "cute") and the desire in that strange age of emerging identities to name oneself. For whatever reason, Putzi was the name I gave myself, clumsily perhaps but also effectively because nobody could confuse Putzi with Willi, my father (A former colleague of mine, when he heard about this project suggested that I should call it "Putzi's Progress").

Thus, for better or worse, Putzi became my pre-school-age name, and I connect it with a carefree, sheltered life on Halle University's research farm, frequent visits from grandparents and doting aunts, very occasional trips to my mother's beloved Schleswig-Holstein, years full of play including playful chores like feeding the hens (5), a near-fatal encounter with a Model $\mathrm{T}$ Ford which crushed my tricycle but not me, with sun in the summer and snow in the winter, just as things should be when you are a child, later in the company of Didi and Spatzi, my two brothers who also quickly outgrew their childhood names (6).

The final onomastic demise of Putzi came just after Easter 1933 when, not yet six, I was required to attend to the daily task, Monday through Saturday, of going to school. The first day was made very much easier by a tradition, still observed today, of the Zuckertüte, a cone-shaped receptacle coming in all sorts of sizes, of which mine was not the smallest, filled with a variety of sweets (7). This would be handed to brand-new first-graders by their mothers, anxiously awaiting their offsprings' reemergence from the school portals that had swallowed them up earlier for the incredible ordeal of one or two initial hours in a classroom with thirty or so other children, in my case, because of the system prevailing at the time, all of them boys. A photograph shows me on the way home, none the worse for that daunting experience, proudly clutching my Zuckertüte in keen anticipation of the demolition of its content. This may well be the 
first picture of the post-Putzi Willi, for I am told that, on the eve of my first schoolday, I declared in full appreciation of the rite of passage: "Now Putzi is no longer Putzi; from now on Putzi will be Willi;" and Willi I have been in my family ever since, for nobody dared oppose such a determined and, I think, reasonable edict. Cloaking one's new identity -in this case, that of a schoolboy -- in a different name is obviously not a recent discovery by name scholars but an instinctive response by the naively and innocently young (or do I detect in Putzi's determined decree an early act of the future onomastician?)

Well, determined and timely the act may have been for it placed the newly renamed Willi as an individual in a whole class of little boys whose teacher, now in her nineties, I am still in touch (8). To her I am still Willi Nicolaisen today but in deference to my academic status she refuses to use the familiar "Du" as a form of address, preferring the more formal "Sie." While Willi served well my new public image, it created a fresh ambiguity on the domestic front for now there were again two Willis in the house, my father and myself. This potentially confusing situation was resolved in two ways: When neither of us was present we were referred to in family circles as der grosse Willi and der kleine Willi which at the time apparently distinguished us sufficiently by age, status and generation. As the years went by, however, the two epithets which were employed to distinguish us became less and less applicable if taken literally but I remained der kleine Willi even after my father's death in 1973, and my only surviving aunt still uses that designation although der grosse Willi has unfortunately not been with us anymore for over twenty-five years. The second solution evolved within the closest family circle in which my father, whether present or not, was referred to as Vati, and I thus became the only Willi, neither gross nor klein. A little later -- and I remember being distinctly aware of this and somewhat disturbed by it as a boy -- my parents stopped calling each other Willi and Paula, at least in public, addressing each other instead as Vati and Mutti, switching onomastically from a fundamentally conjugal role to an essentially parental mode of existence and of self-perception. This practice continued until grandchildren came along when Opa and Oma replaced Vati and Mutti in their presence. Otherwise, the latter pair continued right until death separated them.

Willi (9) remained my chief name even after our move to my mother's birthplace, Kiel, in the German north, where my father had been given a professorial appointment at the university in 1935. Indeed, Willi is still my name within my nuclear family, except for the next generation which, acknowledging my avuncular status, calls me Onkel Willi. This is, however, by no means the end of my onomastic story for as soon as I started going to high school, and without any prompting, I was given the same nickname which my father had had in his own high school and student days: Nico. In fact, I shared this fate with my two brothers (10). Among the few of my classmates who survived World War II, there are 
still some who, on the rare occasions on which we meet, will call me Nico and who may not even remember my real first name. Only our Physical Education teacher, for some reason, insisted on calling us Nike, especially in the memorable, though highly critical, phrase, which has entered the Nicolaisen family oral tradition: "The whole Nike family cannot swim!."

It was in the early post-war years that various people outside my family started to call me Wilhelm (11), beginning on the farm on which I worked for a year and a half after my release as a P.O.W. Even during those 18 months there were variations, however: As we almost exclusively spoke Low German (Plattdeutsch) I tended to be called Willem by the farmer, his family and neighbors in the village, with the exception of the farmer's wife who, presumably because I had been cajoled into teaching them English one evening a week (without much success, I must admit), honored me with the classical designation Wilhelmus and continued to call me that until her death a few years ago. Otherwise, however, I had become Wilhelm to my friends and acquaintances from the time I resumed my schooldays which at the end of the war had been severely interrupted, to the time when I was working on my dissertation at the University of Tübingen (12), and beyond.

Two other names, however, enriched and confused, whatever way you want to look at it, my onomastic existence as a student. In early 1950, while I was still at the University of Kiel, I got involved in the English Dramatic Club and, apart from being a hare in first grade in a dramatization of the fable of "The Hare and the Hedgehog" at the age of six, made my acting debut in the part of Nicola in Shaw's "Arms and the Man"(13). As frequently happens among amateur thespians, we started to call each other by our stage names, and I am still in touch with one of the actresses who, in her occasional correspondence, is very uncomfortable calling me anything other than Nicola, while she to me remained Raina and has not become Ursel.

The other additional name had more serious repercussions because it involved not just a switch in the linguistic register but a change from one language to another, in this case from German to English. When, in April 1950, I first stepped onto English soil as an exchange student at King's College Newcastle, now the University of Newcastle, I was immediately and without being consulted in the matter called Billy -- by professors, fellow students, my landlady, and others (14). I am glad to say that this name did not survive my stay in Newcastle and the summer which followed (including a short spell on a farm near Bridgwater in Somerset), for I never took to it; it somehow was not me, at least not from my own point of view, although others who had known me for only a short time appeared to have no difficulty in equating it with me. I might have been happier with it as a younger boy but at the time I was in my twenties Billy seemed so immature, so juvenile, so insubstantial, almost trivial.

One year later, however, I graduated to my real name, and this happened in connection with my first full-time academic appointment at 
the University of Glasgow which was also, although it could not have been foreseen at the time, the beginning of an academic career in Englishspeaking countries, a career which has lasted for more than 47 years. I do not know who first called me Bill, nor do I remember whether I actively discouraged people from calling me Billy again, but certainly Bill I became and have stayed ever since (15). It is as if all the other names had just been preparations or rehearsals for this one and as if Bill then perfectly expressed who I was meant to be. Undoubtedly, more people know me as Bill or Bill Nicolaisen now than by any other name. Naturally, such people are chiefly speakers of English but even to German speakers who have met me since 1951 I am now usually Bill. In that respect, I was particularly touched when my mother started referring to me as Bill when my wife was around. Anyhow, the person who first called me Bill deserves a medal.

What else was there in store for me? Marriage in Scotland in 1958 and fatherhood in 1959 (16) earned me the name of Dad or Daddy, finally in quadruplicate (17), to which was added in due course the title of Opa (Grandpa). Professionally, Dr. Nicolaisen made his appearance in the University of Edinburgh in 1956 (although I was and still am Willie Nick to some of my former colleagues there), and the first time anybody ever addressed me as Professor Nicolaisen or just plain Professor was during my visiting professorship at Ohio State University in 1966-1967 (18). This appellation is still with me now although one generation of graduate students a few years ago chose to call me, among themselves, "Nickey." As a publishing scholar -- in contradistinction to my father who was also a well-published academic -- I started out as Wilhelm F.H. Nicolaisen but soon decided on the initials W.F.H., the old Wilhelm Fritz Hermann reduced to an acronym (19); curiously, though, and for no reason I can discern, the order of these initials is frequently changed by all kinds of people on both sides of the Atlantic, especially by editors, and I am as often as not referred to as W.H.F. which I am not and which sounds more like the call sign of a radio station. Similarly, the first initial is sometimes expanded to William, or much to my chagrin, to Will, which I am not either. What's good enough for Shakespeare is not necessarily good enough for Nicolaisen. I regard these aberrant variants not as true names of mine, not even as acceptable variants, but as mistakes that have more to say about the people who use them than about me.

This also applies to various erroneous pronunciations of my surname -like [niko'le:sən] or [niko'la-i-sən] -- which seem to have become inevitable though not less annoying whereas [niko'larson], with a voiceless fricative, instead of the German [niko'larzən], with its voiced counterpart, has become the norm and more than just acceptable, especially since my father also used that pronunciation, having been brought up close to the Danish border where Danish has influenced the language of his birthplace, Flensburg. I am pleased to be Bill Nicolaisen and undoubtedly will 
remain so (20). Perhaps an anecdote illustrating the dangers involved in insisting on retaining one's surname more or less intact in a different linguistic and cultural environment, rather than changing it to Nicolson or MacNicol, may be illuminating at this point: When we still lived in Edinburgh, from time to time I had to take shoes to the cobbler's or a suit to the cleaner's, and almost invariably after giving my name as Nicolaisen, I was asked "How do you spell that?". I thought I might be able to avoid this question and therefore on one occasion gave my name as Nicolson whereupon I was asked "With or without an -h-?". When I explained that it did not matter because it was not Nicolson anyhow, the shop attendant almost refused to take my suit! What can one say?

Allow me to add a few more allonyms which are infrequent in their application: Some old-fashioned academics on both sides of the Atlantic refer to me simple by my surname -- Nicolaisen. A few of my Scottish friends who are native speakers of Gaelic sometimes Gaelicize my surname into Uilleam MacNeacail(l); the Anglicized form of the latter is, of course, MacNicol(l). A couple of nephews and nieces and a few young children of family friends call me Uncle Bill, and one German niece whose legal guardian I was when she was staying in upstate New York while attending Vestal High School for a semester, still addresses me as Guardian. I should perhaps also point out that Putzi has not been the only self-imposed name. On a family tour of Germany, the eleven-year old Willi decided to call himself Alter Mann (Old Man), and almost fifty years later I told the students in our London Program that I was Big Bad Bill (in both these instances I used to speak of myself in the third person). Both of these names did not outlast their specific short-term usage but I find the use of the third person that went with it, as it had done with Putzi, a fascinating way of looking at oneself from the outside and of relinquishing one's first-person egocentricity.

So, what is my onomastic identity now after 70 years of meandering shaping and reshaping? Well, it is obviously centrally enshrined in Bill or Bill Nicolaisen but the issue is not that simple, and I have often wondered if I have any identity at all since I am so many names to so many people. Let me try to list these allonyms: Bill, Bill Nicolaisen, Uncle Bill, Willi, der kleine Willi, Onkel Willi, Willi Nicolaisen, Wilhelm, Wilhelm Nicolaisen, W.F.H. Nicolaisen, Nicolaisen, Nico, Nicola, Guardian, Dr. Nicolaisen, Willie Nick, Professor Nicolaisen, Professor, Dad, Daddy, $O p a$, and, of course, good old birth-certificate Wilhelm Fritz Hermann Nicolaisen. What a bewildering array! And how important the socioonomastic aspects are of this list, like register and usage! I respond to all these names in their appropriate situations, and each one of them presents or reflects a different side of me to the world, and to myself, I presume.

To round off this onomastic autobiography of mine, here is a final image based on a photograph taken by my good friend Professor Eichler (21): In March 1980, I had an opportunity to revisit my birthplace Halle for the first time in almost forty years and, in the process, got very close 


\section{Names 47.3 (September 1999)}

to where Putzi had grown up but not close enough, for the authorities of what was then still East Germany, the DDR, had put a wire fence round the whole property and a very securely locked gate across the path along which the newly transformed Willi had proudly marched home with his Zuckertüte in 1933. The house itself, or what one could see of it in the middle distance in the sulphurous smog, looked neglected and in considerable need of repair. It also looked smaller. When I studied this photograph again of Professor W.F.H. Nicolaisen or Bill standing outside the gate and barred from Putzi's home, it occurred to me that this is probably as close as we will ever get to our childhood again, to our past as place, and that even documents, a set of pictures, and a series of names will not help us to do more than reminisce about the children we imagine ourselves to have once been. Even an onomastic autobiography can do no more than create true chunks of a past that never was. Presumably it is at this point that "story" and "history" regain their original etymological unity. Nevertheless, Bill Nicolaisen's account of Putzi's Progress is bound to remain just that -- Bill Nicolaisen's account of Putzi's Progress, and not Putzi's or Willi's or Nico's own unfiltered, unrefracted stories.

\section{Notes}

1. The figures in parenthesis refer to the numbered illustrations in the photographic section.

2. This is an updated and slightly revised version of a paper first read at the 1992 annual conference of the Canadian Society for the Study of Names, in Prince Edward Island, and later presented at the Eighteenth International Congress of Onomastic Sciences in 1993, in Trier (Germany). 
An Onomastic Autobiography 187

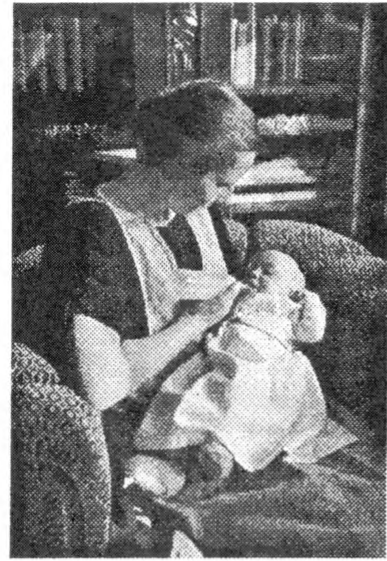

1. Mother and Son (October 1927), Halle/Saale.

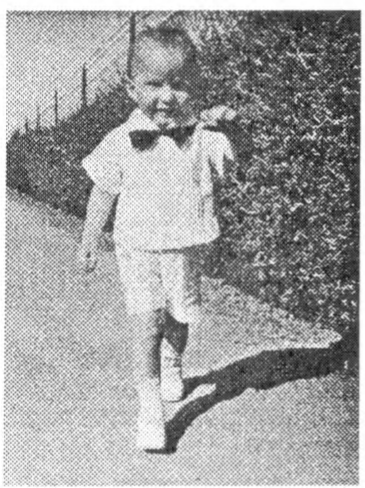

4. Putzi (May/June 1929), Halle/Saale.

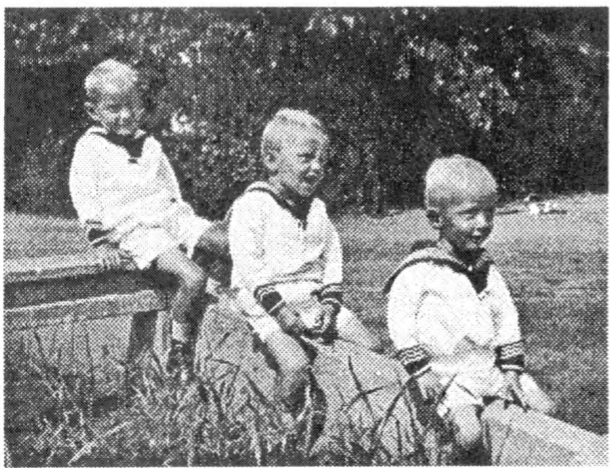

6. Putzi, Didi (Dieter), Spatzi (Heiner), Halle/Saale (July 1932)

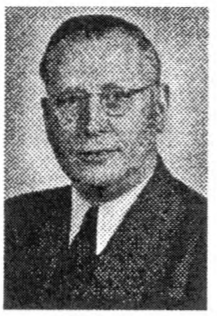

2. Father (in the

1950s), Hanover.

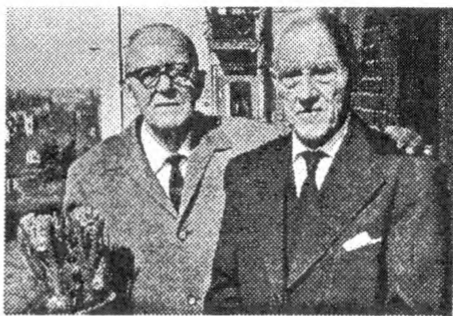

3. Grandfathers Fritz Nicolaisen and Hermann Kähler (1960s), Flensburg.

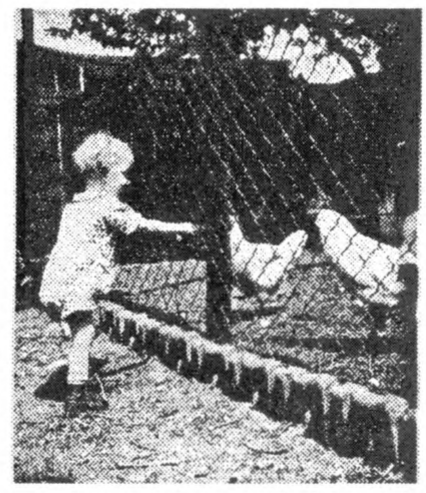

5. Putzi (1928), Halle/Saale.

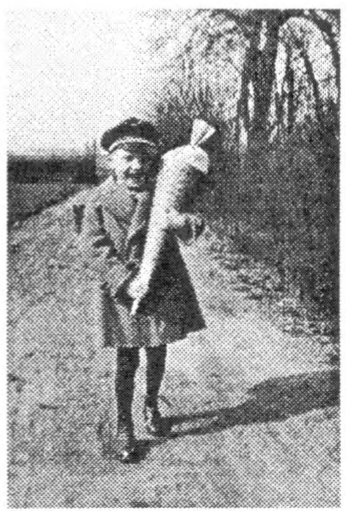

7. Willi's first day at school (April 1933), Halle/Saale. 


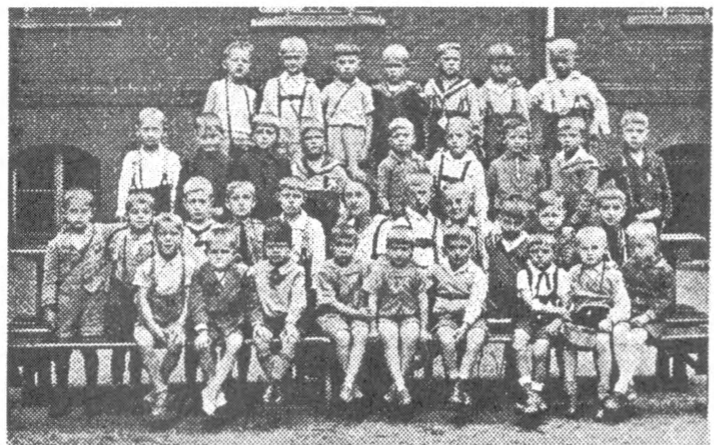

8. First year at Freiimfelder Volksschule, Halle/Saale.

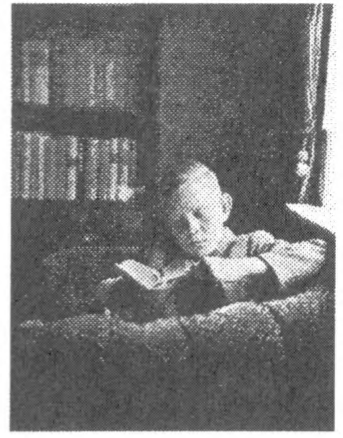

9. Always a reader (c. 1937-8), Kiel.

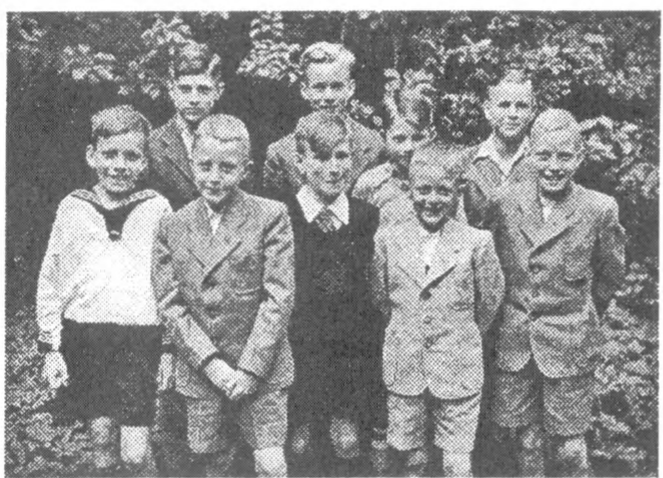

10. Birthday party (June 1937), Kiel.

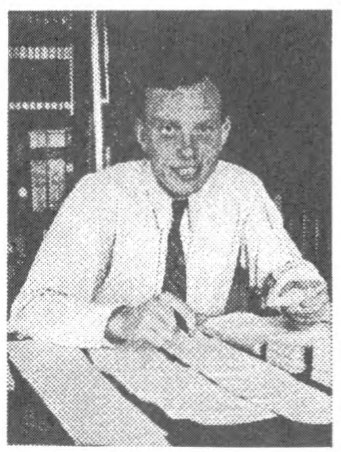

12. At work on Ph.D. dissertation (1954), Tübingen.

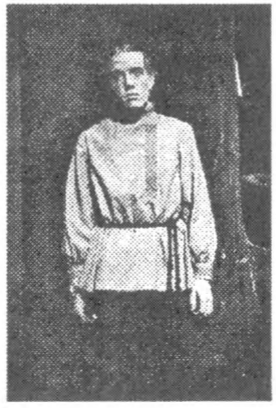

13. As Nicola in Shaw's Arms and the Man (January 1950), Plön, nr. Kiel.

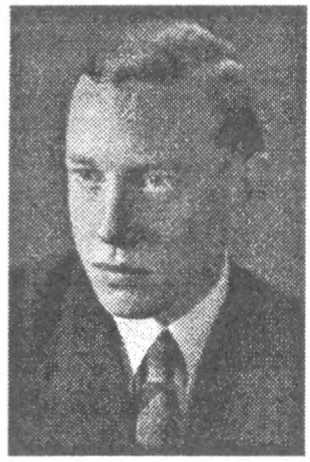

11. School-leaver (May 1948), Herford.

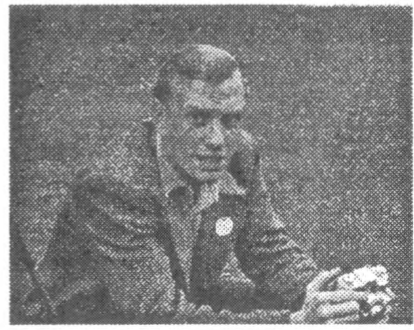

14. Billy at Capernwray Hall, Lancs. (September 1951). 


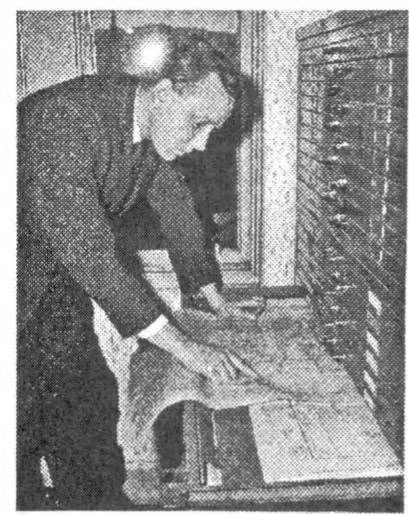

15. Head of Scottish PlaceName Survey, School of Scottish Studies (195669), Edinburgh

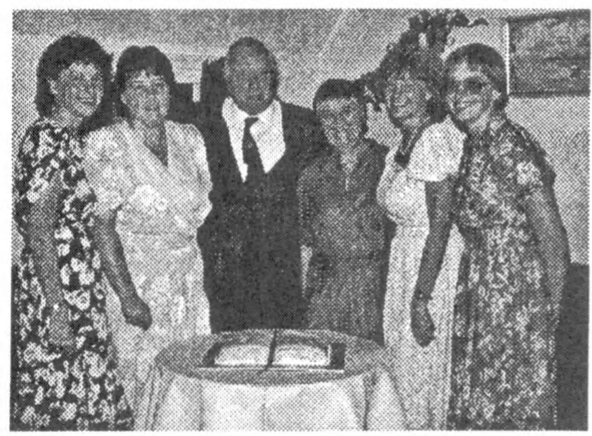

17. With wife May and daughters Fiona, Kirsten, Moira, and Birgit on $60^{\text {th }}$ birthday (June 1987), Edinburgh.

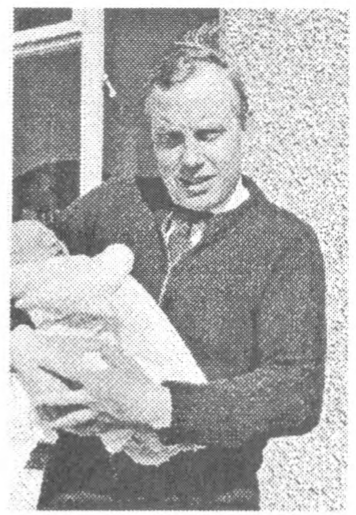

16. Daddy and daughter Fiona (October, 1959), Edinburgh.

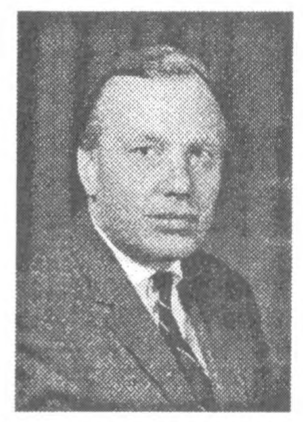

18. Visiting Professor at Ohio State University (1966-7), Columbus, Ohio.

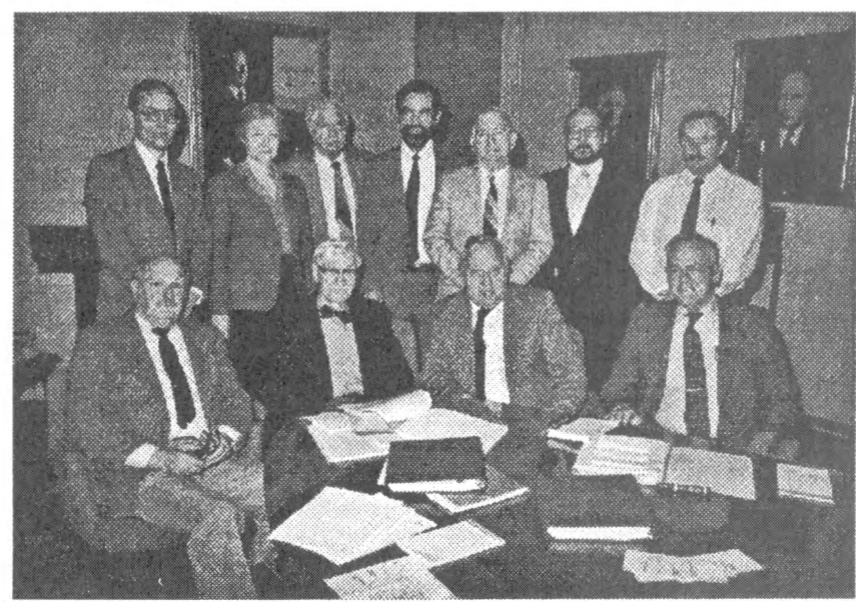

19. PLANSUS Meeting (c. 1991), Washington, D.C. 


\section{Names 47.3 (September 1999)}

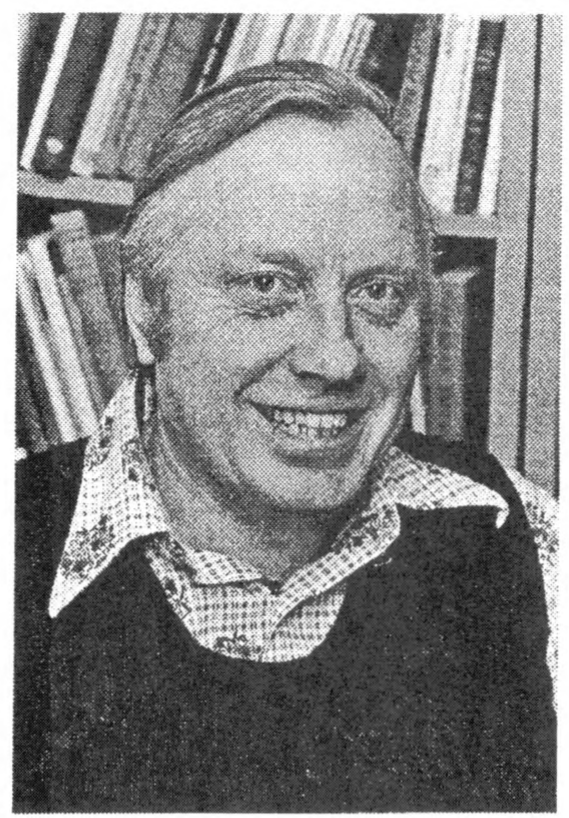

20. Distinguished Professor of English and Folklore, State University of New York at Binghamton (1969-92).

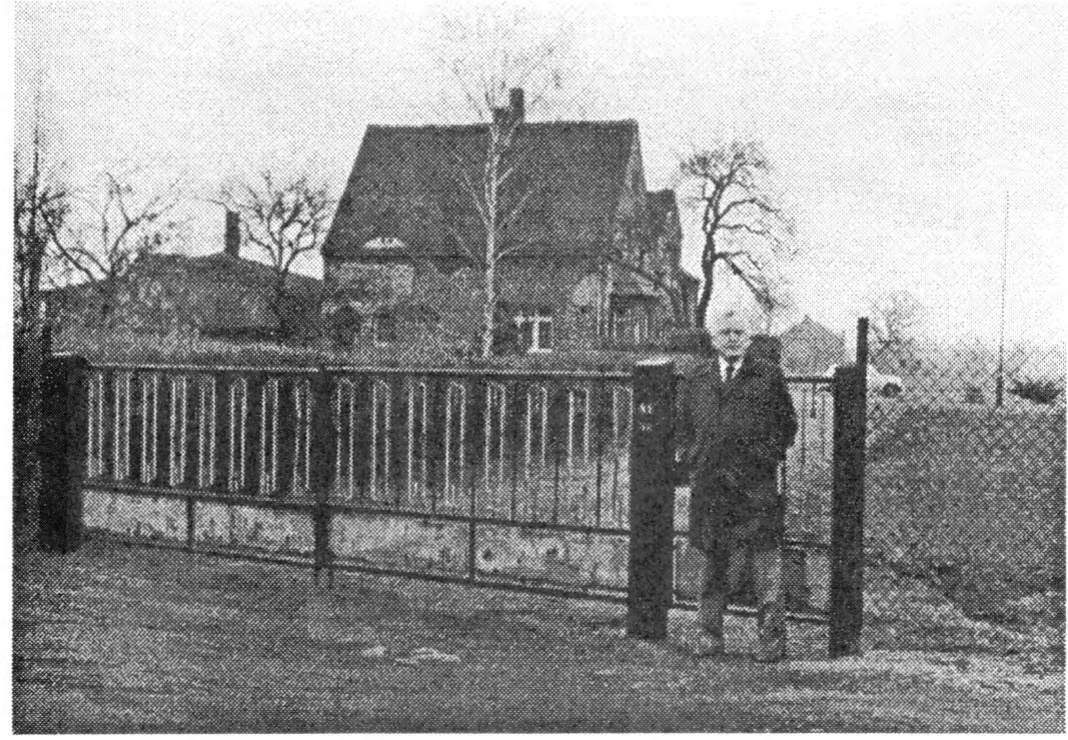

21. Outside boyhood home, Halle/Saale (March 1980). 